\title{
Effective Adolescent Sexual and Reproductive Health Education Programs in Sub-Saharan Africa
}

\author{
Fatch W. Kalembo ${ }^{1,2}$, Maggie Zgambo ${ }^{3}$, and Du Yukai ${ }^{1}$ \\ ${ }^{1}$ Huazhong University of Science and Technology \\ ${ }^{2}$ Mzuzu University \\ ${ }^{3}$ University of North Carolina Project
}

\begin{abstract}
Background: The objective of this review was to explore and identify feasible, socially acceptable and effective adolescent sexual and reproductive health education (ASRHE) programs in sub-Saharan Africa. Methods: Four databases were searched to identify studies conducted within the past 15 years which evaluate the effectiveness of ASRHE programs in sub-Saharan Africa. The databases searched were Embase, Medline, CINAHL, PyscINFO. A further search for relevant articles was made in the Google scholar website. The title and abstract of each article were analyzed for relevance by applying inclusion and exclusion criteria. Further scrutiny and extraction of the studies was completed by selecting only those studies which met the criteria for inclusion. Results: Fifteen studies were identified. School, peer, mass media, health facility and community based ASRHE programs showed positive impact in one or more of the following outcomes in adolescents in sub-Saharan Africa: ( i) knowledge of HIV transmission; (ii) perceived personal risk of contracting HIV/ AIDS; (iii) self-efficacy to negotiate condom use; (iv) discussion with others about HIV/AIDS or condom use; (v) abstinence from sexual relations; (vi) reduction in high-risk sexual behavior; (vii) condom use (vii) testing for sexually transmitted infection (STI) and (viii) treatment seeking behavior. Conclusion: ASRHE programs of diverse forms can produce positive change in adolescent sexual and reproductive health (ASRH). There is need for rigorous research to assess long term behavioral effects of culturally tailored comprehensive ASRHE programs in sub-Saharan Africa.
\end{abstract}

(C) 2013 Californian Journal of Health Promotion. All rights reserved.

Keywords: adolescents, sexual and reproductive health, health education, sub-Saharan Africa

\section{Introduction}

Sub Saharan Africa has experienced very high rates of unemployment and poverty among young people aged 15 to 24 (United Nations, 2011). Poverty and reproductive health are intricately related. Poverty is associated with high-risk behaviors, such as rape and unsafe sex in exchange for monetary incentives. These behaviors put young women at risk of unintended pregnancy and sexually transmitted infections such as HIV, which in turn affect their reproductive health (USAID, 2009). Poverty and inadequate healthcare systems compound the vulnerability of young women to sickness and early death. Young teen mothers are at high risk of experiencing serious complications during pregnancy and childbirth because their bodies often have not yet fully matured (Bernstein \& Hansen, 2006). The proportion of births that take place during adolescence is about $2 \%$ in China, $18 \%$ in Latin America and the Caribbean and more than $50 \%$ in sub-Saharan Africa (WHO, 2011).

In sub-Saharan Africa, 3.2 million young people are living with HIV and three young women are infected for every young man (UNAIDS, 2008). Moreover 75 percent of all new cases of HIV in 
this region are found among young women and girls between ages 15-24 years (Global Health Council, 2007).Young people have special sexual and reproductive health needs because of their relatively higher risk of being exposed to inaccurate or incomplete information, which leads them to acquiring HIV and other sexually transmitted infections (STIs), and experiencing unintended pregnancies and maternal complications (Rani \&Lule, 2004).

At the 1994 International Conference on Population and Development (ICPD), the program of action signed by 179 countries called for the protection and promotion of the rights of adolescents to reproductive health education, information and care, and a reduction in sexually transmitted infections and pregnancy. The United Nation Population Fund (UNFPA) adopted Millennium Development Goals (MDGs) to complement the ICPD program of action in an effort to improve the reproductive health of young people. The MDGs are a framework for progress consisting of eight MDGs which were derived at the Millennium Summit in 2000 by leaders of 189 member states. The MDGs serve as a time-bound, achievable blueprint for reducing poverty and improving lives (UNFPA, 2010).

The ICPD program of action is aligned with the MDGs' focus on education. Education is not only a goal in itself as state by the millennium development goal number two (MDG2), but fundamental to eradicating poverty and hunger (MDG1). Education and health care for young people are essential to reduce child and infant mortality and HIV infection (MDG4, MDG5, and MDG6) as well as the promotion of gender equality and empowerment of women (MDG3). Young people should be provided with access to comprehensive and culturally appropriate sexual and reproductive health education in schools (UNFPA 2011). The purpose of this review therefore, was to explore and identify feasible, socially acceptable and effective ASRHE programs in sub-Saharan Africa. The review was conducted as a follow up on goals set forth at the 1994 ICPD to promote ASRH. It was aimed at measuring the progress made so far in subSaharan Africa in meeting the ICPD goals.

\section{Methods}

\section{Inclusion and Exclusion Criteria}

For inclusion in the review, studies had to have been original peer-reviewed research articles conducted in sub-Saharan Africa and published in English from 1996 to 2011. The studies had to address ASRHE programs and focus on adolescents aged 10-24. In addition studies had to include the programmatic effect on one or more of the following outcomes: Sexual behaviors, initiation of sex, frequency of sex, number of sexual partner(s), use of condoms, use of contraceptives, pregnancy rates, STI rates, increased knowledge of reproductive health matters, and attitudes and beliefs on sexual and reproductive issues. Studies also had to use randomized controlled trials or a quasiexperimental design to evaluate the effectiveness of ASRHE programs.

\section{Data Sources}

The databases searched were Embase, Medline, CINAHL and PsycINFO. A further search for relevant articles was made in the Google scholar website. The title and abstract of each article were analyzed for relevance by applying inclusion and exclusion criteria. Further scrutiny of the studies was done by selecting only those studies which met the inclusion and exclusion criteria. The search terms used in the electronic data bases were: adolescents and reproductive health education, health promotion, and sexual and reproductive health.

\section{Data Extraction}

The combined searches resulted in 780 articles. The articles were screened for eligibility and 31 full-text articles were obtained for further assessment. Out of 31 articles, only 15 met the inclusion criteria and were included in the review.

\section{Results}

The review included 13 quasi experimental design studies and two randomized controlled trials. The Studies reviewed were conducted in 10 sub-Saharan countries; one in Zambia (Agha \& Van Rossem, 2004), two in Zimbabwe (Mbizvo, Kasule, \& Gupta, 1997; Kim, Kos, 
Nyakauru, Marangwanda, \& Chibatamoto, 2001), one in Uganda (Shuey,1999), one in Kenya (Erulkar, Ettyang, Onoka, Nyagah, \& Muyonga, 2004), one in Botswana (Agha, 2002), two in South Africa (Jones, Mathews, Flisher, 2011; Agha, 2002), one in Ghana (Brieger, Delano, Lane, Oladepo, \& Oyediran, 2001), one in Guinea (Agha, 2002), one in Cameroon (Agha, 2002) and five in Nigeria (Esere, 2008 ; Fawole, Asuzu, Oduntan, \& Brieger, 2009; Okonofua et al., 2003; Brieger, Delano, Lane, Oladepo, \& Oyediran, 2001; Akpabio, Asuzu \& Boluwani, 2009). The results are presented under the following subheadings: School, peer, mass media, health facility and community based ASRHE programs. All the studies had intervention and comparison groups. Pre-test and post intervention assessment were completed in order to measure the effectiveness of ASRH programs. Odds ratios were used to determine the level of effectiveness of ASRHE programs. A Summary of the results is presented in Tables 1-5. Below is the description of the results.

\section{School Based ASRHE Program}

Interventions were implemented by both teachers as part of primary and secondary school curricula, and research staff after school hours. In this category four studies were identified (see Table 1). These studies revealed a statistically significant difference between the intervention and control groups in relation to risky sexual behaviors. Adolescents in the intervention group reported less at-risk sexual behaviors than their control group counterparts. Knowledge of sexual and reproductive health, family planning and transmission and prevention of STIs and AIDS was found to be significantly higher in the intervention group than in the control group. (Fawole, 2009; Mbivo et al., 1997; Esere, 2008 ; Shuey et al., 1999).

\section{Peer-Led ASRHE Program}

Peer education is a flexible approach that can be used in many different contexts (e.g. schools, youth clubs and community). Three studies were identified in this category (see Table 2). The intervention group was exposed to peercounseling, education on ASRH, referral to youth friendly clinics and information, education and communication (IEC). Only one study showed a positive impact of the intervention on the use of condoms and reduction in the number of sexual partners (Agha et al., 2004). The other two studies in this group showed no significant difference in the use of condoms and modern contraception between the intervention and control groups (Agha et al., 2004; Brieger et al., 2001).

\section{Mass Media ASRHE Program}

Use of the media covers a wide spectrum of different approaches, from the distribution of printed IEC materials at health centers, schools, workplaces and other locations to comprehensive mass media campaigns using television and radio. We identified four studies in this category (see Table 3). All of them had the same evaluation design (quasi experimental) and were conducted by the same investigator (Agha, 2002). The comparison of pre- and postinterventional assessment revealed that the intervention group had a net positive impact on female adolescents' likelihood of perceiving that sexual activity carries the risk of pregnancy and the benefits of abstinence or condom use. The results of these studies also showed that the interventions had a small positive impact on perceived barriers to practicing safe sex.

\section{Health Facility Based ASRHE Program}

These are ASRH interventions either carried out by health workers or carried out in a health facility setting. We identified two studies in this category, both conducted in Nigeria (see Table 4). Results of the two studies revealed that youth in the intervention groups reported significant improvements in knowledge and attitudes towards prevention of STIs, use of condoms, STIs partner notification and treatment seeking behaviors as compared to the control groups (Akpabio, 2009; Okonofua et al., 2003).

\section{Community Based ASRHE Program}

These are interventions provided to adolescents in their communities that seek to modify individual attitudes, beliefs, values and behaviors around sexual and reproductive health. We identified two studies in this category (Kim et al., 2001; Erulkar et al., 2003) (see Table 5). In both studies, youth in the 
Table 1

Outcomes of School Based ASRHE Program on ASRH Knowledge, Attitudes and Behaviors

\begin{tabular}{llll}
\hline Author(s), Year, Setting, & Intervention(s) & Outcome & Findings \\
Participants \& Study & & Measures & \\
\hline
\end{tabular}

Design.

Esere (2008). Nigerian

adolescents $(\mathrm{n}=24)$, aged

between 13-19 years.

School based program.

Quasi experimental design.

Shuey, Babishangire, Omiat \& Bagarukayo (1999). Ugandan adolescents $(n=400)$, aged between 13 - 14 years. School based program. Quasi experimental design.

Fawole, Asuzu, Oduntan \& Brieger (1999). Nigerian adolescents $(\mathrm{n}=440), 13$ 20 years old. School based program. Quasi experimental study.

Mbizvo, Kasule \& Gupta (1997). Zimbabwean adolescents $(n=689)$ with mean age of $14.6 \pm 3.1$ years. School based program. Randomized controlled study.
Participants in the Intervention group were given sex education and those in the control group were given a placebo.

Participants in the intervention groups were given peer education related to HIV, sexuality and health. Involvement of community and parents in ASRH activities.

Six sessions of comprehensive sexual education. Experimental activities e.g. role plays and demonstrations on proper use of condoms. Referral of students to reproductive and sexual health clinics.

Participants were provided with ASRHE through posters and pamphlets.
Self-reported exposure to STIs, multiple sexual partners, anal sex, oral sex, non-use of condoms.

Knowledge, attitudes and practices on sexuality and HIV /AIDS.

Knowledge on HIV/AIDS transmission and prevention. Attitudes towards AIDS as a disease. Number of reported sexual partners. Condom use.

Knowledge on reproductive biology, sexual behavior and contraception
- Analysis of covariance results indicated that the intervention group reported less at - risk sexual behaviors, and their knowledge of sexual health improved. $(\mathrm{p}<0.05)$
- The number of participants in the intervention group who discussed sexual matters with schoolmates increased from $30 \%$ to $50 \%(\mathrm{p}<0.001)$, while the change in the control groups increased from $29 \%$ to $36 \%(\mathrm{p}<0.05)$.

- $\quad$ Analysis of variance and $\chi^{2}$ results indicated a statistically significant difference in knowledge on transmission and prevention of AIDS $(p<0.05)$ which was higher among participants in the intervention group than the control group.

- Participants in the intervention group demonstrated positive attitude towards people with AIDS.

- There was a significant increase in use of condoms among participants in the intervention group than those in the control group.

Wilcoxon two- sample test results indicated

- An increase in correct knowledge about aspects of menstruation $(\mathrm{OR}=2.0,95 \% \mathrm{CI}=$ 1.1-3.9). The increase was higher among students in intervention group than those in the control group.

- An increase in knowledge of family planning. The increase was higher in the intervention group $(\mathrm{OR}=14.4,95 \% \mathrm{CI}=1.1$ 1.7).

- $\quad$ The proportion of pupils who reported having had sexual intercourse decreased significantly in the intervention group than the control group. intervention sites were exposed to comprehensive sexual health programs. The intervention sites reported a statistically significant increase in communication about sexual issues with anyone, delayed initiation of sexual intercourse, increased abstinence, reduced number of sexual partners, increased use of contraception, increased condom use and increased use of health services.

\section{Discussion}

The results of this review indicate that school, peer, mass media, health facility and community based ASRHE programs have a positive impact on one or more of the following outcomes in 
Table 2

The Impact of Peer- Led ASRHE Program on ASRH Knowledge, Attitudes and Behaviors

\begin{tabular}{|c|c|c|c|}
\hline $\begin{array}{l}\text { Author (s), Year, Setting, } \\
\text { Participants \& Study } \\
\text { Design. }\end{array}$ & Intervention (s) & $\begin{array}{l}\text { Outcome } \\
\text { Measures }\end{array}$ & Findings \\
\hline $\begin{array}{l}\text { Agha (2004). Zambian } \\
\text { adolescents ( } \mathrm{n}=416), 14- \\
23 \text { years old. School based } \\
\text { program. Quasi- } \\
\text { experimental design. }\end{array}$ & $\begin{array}{l}\text { Participants in the intervention } \\
\text { group were exposed to peer } \\
\text { education session on HIV/AIDS } \\
\text { prevention whereas those in the } \\
\text { control group were exposed to } \\
\text { peer education on water } \\
\text { purification. Follow up survey } \\
\text { was conducted } 8 \text { months after } \\
\text { initiation of interventions. }\end{array}$ & $\begin{array}{l}\text { Student self- } \\
\text { reports in } \\
\text { normative } \\
\text { beliefs about } \\
\text { abstinence. } \\
\text { Likelihood to } \\
\text { approve and use } \\
\text { of condoms. }\end{array}$ & $\begin{array}{l}\text { Logistic regression results indicated that } \\
\text { - Students in the intervention group } \\
\text { showed significant changes in } \\
\text { normative beliefs about abstinence } \\
\text { and condom use. } \\
\text { - There was no significant change } \\
\text { observed in both intervention } \\
\text { and control groups in condom } \\
\text { use. }\end{array}$ \\
\hline $\begin{array}{l}\text { Brieger, Delano, Lane, } \\
\text { Oladepo \& Oyediran } \\
(2001) . \text { Nigerian and } \\
\text { Ghanaian Youths ( } \mathrm{n}= \\
3,585) \text {, below } 25 \text { years } \\
\text { old. Community and } \\
\text { school based program } \\
\text { Quasi experimental } \\
\text { design. }\end{array}$ & $\begin{array}{l}\text { Peer educators provided the } \\
\text { following interventions to the } \\
\text { youth; one to one counseling on } \\
\text { ASRH, group education on } \\
\text { ASRH issues, referrals to health } \\
\text { facilities. }\end{array}$ & $\begin{array}{l}\text { Knowledge, } \\
\text { attitudes and } \\
\text { practices on use } \\
\text { of condoms and } \\
\text { contraception }\end{array}$ & $\begin{array}{l}\text { Youth in the intervention group } \\
\text { scored significantly higher on use of } \\
\text { condoms than their control } \\
\text { counterparts }(p<0.001)\end{array}$ \\
\hline $\begin{array}{l}\text { Jones, Mathews \& Flisher } \\
\text { (2011). South African } \\
\text { adolescents, }(n=3,934) \text {, } \\
\text { age not indicated. School } \\
\text { based program. Quasi } \\
\text { experimental design. }\end{array}$ & $\begin{array}{l}\text { Peer educators provided } \\
\text { ASRHE to their fellow } \\
\text { students. }\end{array}$ & $\begin{array}{l}\text { Sexual health } \\
\text { behaviors and } \\
\text { related } \\
\text { psychosocial } \\
\text { outcomes }\end{array}$ & $\begin{array}{l}\text { - There was no statistically significant } \\
\text { difference between participants in the } \\
\text { intervention and the control groups } \\
\text { on age of sexual debut, use of } \\
\text { condoms, decisional making and } \\
\text { future orientation }(\mathrm{p}>0.05) \text {. }\end{array}$ \\
\hline
\end{tabular}

adolescents in sub-Saharan Africa: (i) knowledge of HIV transmission; (ii) perceived personal risk of contracting HIV/ AIDS; (iii) self-efficacy to negotiate condom use; (iv) discussion with others about HIV/AIDS or condom use; (v) abstinence from sexual relations; (vi) reduction in high-risk sexual behavior; (vii) condom use (vii) testing for STI and (viii) treatment seeking behavior.

The results of the review suggest that ASRHE programs in sub-Saharan Africa are effective in enhancing positive knowledge, attitudes and behavioral change in adolescents towards their sexual and reproductive health. While school, health facility, and community based ASRHE programs showed positive outcomes in changing knowledge, attitudes and behavior related to ASRH outcomes, mass media failed to show positive changes in attitudes towards abstinence and condom use in the prevention of STI and HIV/AIDS. A comparative study of mass media ASRHE in the United States of America (USA) showed positive results when culturally tailored mass media messages were delivered consistently over time (more than 3 years) (Sznitman et al., 2011). The socio-economic difference between the USA and sub-Saharan Africa can best explain the difference in effectiveness of mass media in enhancing ASRH. For instance, more than half of the children in the United States are estimated to have a television set in their bedroom (Roberts, Foehr, Rideout, \& Brodie, 1999). On the contrary, in the sub-Saharan region, few families can afford to buy television sets for their homes. This is an area that governmental and nongovernmental organizations in sub-Saharan Africa need to explore and invest in because of its potential to reach both in-school and out of school adolescents. This can be achieved by establishing youth centers in communities which are equipped with audio-visual facilities and sponsoring adolescents' sexual and reproductive health campaigns on local and national television stations. These centers should be 
Table 3

Summary of Studies on Effectiveness of Mass Media ASRHE Program

\begin{tabular}{|c|c|c|c|}
\hline $\begin{array}{l}\text { Author (s), Year, } \\
\text { Setting, Participants } \\
\text { \& Study Design. }\end{array}$ & Intervention(s) & $\begin{array}{l}\text { Outcome } \\
\text { Measures }\end{array}$ & Findings \\
\hline $\begin{array}{l}\text { Agha (2002). } \\
\text { Adolescent in } \\
\text { communities, aged } \\
\text { between } 13 \text { and } 20 \\
\text { years ( } \mathrm{n}=221,2,396, \\
1,633 \text { and } 2,016) \text { in } \\
\text { South Africa, } \\
\text { Botswana, Cameroon, } \\
\text { and Guinea } \\
\text { respectively. Quasi } \\
\text { experimental design. }\end{array}$ & $\begin{array}{l}\text { Adolescents in } \\
\text { intervention group } \\
\text { were exposed to } \\
\text { ASRH messages. } \\
\text { Promotion of } \\
\text { condoms use through } \\
\text { print media, } \\
\text { television, radio and } \\
\text { youth friendly } \\
\text { services. Intervention } \\
\text { period varied from } 8 \\
\text { to } 13 \text { months in the } \\
\text { four countries. }\end{array}$ & $\begin{array}{l}\text { Perceptions } \\
\text { and } \\
\text { behaviors } \\
\text { related to } \\
\text { sexual } \\
\text { health and } \\
\text { risks. }\end{array}$ & $\begin{array}{l}\text { Multivariate logistic regression results indicated that the } \\
\text { interventions had net positive impact on women } \\
\text { likelihood of perceiving that sexual activity carries the } \\
\text { risk of pregnancy in the intervention groups in } \\
\text { Botswana, and South Africa while in Cameroon and } \\
\text { Guinea the interventions had no net effect. } \\
\text { Interventions carried out in Cameroon, Botswana and } \\
\text { South Africa had no net positive impact on women's } \\
\text { perception of the benefits of abstinence and condom use } \\
\text { while in Guinea, the interventions had net positive } \\
\text { impact. } \\
\text { In Cameroon, the interventions had a small positive } \\
\text { impact on perceived barriers to practicing safe sex while } \\
\text { in South Africa, Botswana and guinea the interventions } \\
\text { had no net positive impact. }\end{array}$ \\
\hline
\end{tabular}

available to the youth at no charge. This is backed up by a study conducted by Strasburger (2004) in the USA, which revealed that children and adolescents spend an inordinate amount of time with media, more time, in fact, than they spend in any leisure-time activity except sleeping.

Peer-led ASRHE programs showed limited behavioral change in adolescents especially on condom use. In South Africa, the peer-led ASRHE failed to produce significant results. Similar findings were found in a systematic literature review conducted for low and middle income countries which found that peer-educator led programs may not be the most effective at changing sexual behavior (Tyndale \& Penwell, 2010). On the other hand, studies in the USA demonstrated that peer-led ASRHE programs were effective in enhancing ASRHE (Boyer, Sieverding, Siller, Gallareadc, \& Chang, 2007; Cupples, Zukoski, \& Dierwechter, 2010; DiClemente et al., 2004). The differences in the peer-led studies between USA and sub-Saharan Africa were rooted in the methodology. For instance, in sub-Saharan Africa peer educators were voluntarily recruited to the program and did not receive further education and supervision after the initial training. In the USA, peer educators were selected by fellow adolescents (Boyer et al., 2007). Peer educators had to undergo a rigorous interview before being recruited in the program and were receiving maximum supervision and in service training (Cupples et al., 2010). The ASRHE program was provided by both peer educators and health educators (DiClemente et al., 2004).

In light of the results from this review, there are several strengths and weaknesses of the studies addressing ASRHE programs in sub-Saharan Africa.

\section{Strengths of the Studies Addressing ASRHE Programs}

We identified three strengths of the studies included in this review. The studies employed different strategies in educating adolescents such as posters, models, demonstrations, films, role play, training of peer educators, and the use of print and electronic media. Similar findings were also found in studies conducted in the USA (Gavin, Catalano, \& Markham, 2010; Cardoza, Docum, Fryer, Gold, \& Butler, 2011). This suggests the need for governments in subSaharan Africa to promote the use of these strategies in ASRHE programs through the development and promotion of policies that enhance the use of these strategies. Furthermore the interventions employed reached both inschool and out of school adolescents. In addition these studies used two strong evaluation designs, randomized controlled trials and quasiexperimental designs. These designs were also 
Table 4

Health Facility Based Research on ASRHE program

\begin{tabular}{|c|c|c|c|}
\hline $\begin{array}{l}\text { Author (s), Year, Setting, } \\
\text { Participants \& Study Design. }\end{array}$ & Intervention(s) & $\begin{array}{l}\text { Outcomes } \\
\text { Measures }\end{array}$ & Findings \\
\hline $\begin{array}{l}\text { Akpabio, Asuzu \& Boluwani } \\
(2009) \text {. Nigerian adolescents } \\
\text { (n=360), 9-20 years old. } \\
\text { School and health facility } \\
\text { based program. Quasi } \\
\text { experimental design. }\end{array}$ & $\begin{array}{l}\text { Students were exposed to } \\
\text { ASRHE in forms of lectures, } \\
\text { posters, model demonstration, } \\
\text { film show and role plays. The } \\
\text { post intervention data collection } \\
\text { was carried out } 3 \text { months after } \\
\text { the educational interventions. }\end{array}$ & $\begin{array}{l}\text { Change in } \\
\text { attitude } \\
\text { towards } \\
\text { HIV/ AIDS } \\
\text { prevention. }\end{array}$ & $\begin{array}{l}\text { The results showed that the } \\
\text { interventions had a significant impact } \\
\text { on students' attitude toward } \\
\text { HIV/AIDS prevention }(\mathrm{p}<0.001) \text {. The } \\
\text { impact was higher in the intervention } \\
\text { group as compared to the control } \\
\text { group. }\end{array}$ \\
\hline
\end{tabular}

Okonofua, Coplan, Collins, Oransaye, Ogunsakin, Ogonor \& Heggehougen (2003). Nigerian adolescents $(\mathrm{n}=1,858), 14-20$ years old. School and health facility based program. Randomized controlled design.
Provision of comprehensive ASRHE, youth-led reproductive health clubs, STIs awareness campaigns, peer education on abstinence. Medical professionals were trained on management of STIs
Knowledge

on STIs treatment and STIs treatment seeking behavior.
- $\quad$ Youth in the intervention group reported an increased use of physicians for STIs treatment (OR $=2.1,95 \% \mathrm{CI}=1.1-4.0)$.

- $\quad$ Significant reduction of STIs symptoms in the intervention group as compared to the control group $(\mathrm{OR}=0.68,95 \% \mathrm{CI}=0.48-0.95)$. found to produce significant results in another systematic review of literature on sexual health behavior interventions for USA Latino adolescents (Cardoza et al., 2011).

\section{Weaknesses of the Studies Addressing ASRHE Programs}

We identified the following weaknesses in the studies included in this review. First, the studies had limited coverage of gender and culturally sensitive interventions. Only one of the fifteen studies employed culturally tailored ASRH interventions. A study in the USA found that teenage males who agree with traditional cultural messages about masculinity were more likely than other young men to use condoms less consistently (or not at all), and to say that if they impregnated a partner, they would feel like a real man (Pleck, Sonenstein, \& Leffert, 1993). Based on the results from the USA study, it is important for researchers in sub-Saharan Africa to include gender and culture related interventions in future research on ASRHE.

Another weakness of studies included in this review was that some of them employed small sample sizes and had consequently reduced power. Sample sizes ranged from as low as 25 to 3934. According to a study conducted by Muyinda and others, statistical power can be compromised by small sample size (Muyinda,
Nakuya, Pool, \& Whitworth, 2003).

Furthermore, out of fifteen studies, only three involved parents and communities in ASRHE programs. Similar findings were found in a study in the USA, where adolescents complained of lack of community involvement in ASRH programs (Akers et al., 2010).

The last weakness in the studies included in this review was that only short-term impacts of ASRH interventions could be reliably evaluated. Only one study had intervention period of more than two years (Erulkar et al., 2004).

\section{Limitations of the Literature Review}

The review has the following limitations; only four databases were used for articles included in the review. Furthermore, only English-language articles were searched. In addition to this, the articles analyzed in this literature review were drawn from ten of the 47 countries in subSaharan Africa. This may diminish the generalizability of the findings to the subSaharan region as a whole.

\section{Conclusion and Recommendations.}

School, community, health facility, mass media and peer-led ASRHE programs have been shown to increase knowledge and promote positive change in attitudes and behaviors 
Table 5

Research on Effectiveness of Community Based ASRHE Program

\begin{tabular}{|c|c|c|c|}
\hline $\begin{array}{l}\text { Author (s), Year, Setting, } \\
\text { Participants \& Study } \\
\text { Design. }\end{array}$ & Intervention (s) & Outcomes Measures & Findings \\
\hline $\begin{array}{l}\text { Kim, Kos, Nyakauru, } \\
\text { Marangwanda \& } \\
\text { Chibatamoto (2001). } \\
\text { Zimbabwean adolescents } \\
\text { (n=1,400), } 10 \text { to } 24 \text { years } \\
\text { old. Community based } \\
\text { program. Quasi } \\
\text { experimental design. }\end{array}$ & $\begin{array}{l}\text { Intervention sites were exposed } \\
\text { to comprehensive sexual health } \\
\text { education. Youth were involved } \\
\text { in designing materials and } \\
\text { messages. Communities were } \\
\text { involved in planning launching } \\
\text { and executing activities. Peer } \\
\text { educators and health workers } \\
\text { were trained on offering youth } \\
\text { friendly services. }\end{array}$ & $\begin{array}{l}\text { Sexual health } \\
\text { behaviors on } \\
\text { communication about } \\
\text { sexual issues, } \\
\text { initiation of sexual } \\
\text { intercourse, } \\
\text { abstinence, number } \\
\text { of sexual partners and } \\
\text { condom use. }\end{array}$ & $\begin{array}{l}\text { Participants in the intervention } \\
\text { sites reported statistically } \\
\text { significant Increase in } \\
\text { communication about sexual } \\
\text { issues with fellow students, } \\
\text { delayed initiation of sexual } \\
\text { intercourse, increased } \\
\text { abstinence, reduced number of } \\
\text { sexual partners, increased use of } \\
\text { contraception and condoms. ( }<< \\
0.001 \text { ) }\end{array}$ \\
\hline $\begin{array}{l}\text { Erulkar, Ettyang, Onoka, } \\
\text { Nyagah \& Muyonga } \\
(2004) \text {. Kenyan } \\
\text { adolescents ( } \mathrm{n}=1,865) \text {, } \\
\text { aged between } 10 \text { to } 24 \\
\text { years. } \\
\text { Community based } \\
\text { program. Quasi } \\
\text { experimental design. }\end{array}$ & $\begin{array}{l}\text { Intervention sites were exposed } \\
\text { to comprehensive sexual health } \\
\text { campaign, community designed } \\
\text { culturally consistent } \\
\text { interventions. Young parents } \\
\text { were involved in providing } \\
\text { ASRHE. Teachers were trained } \\
\text { on providing ASRHE. }\end{array}$ & $\begin{array}{l}\text { Sexual health } \\
\text { behaviors on } \\
\text { communication about } \\
\text { sexual issues, } \\
\text { initiation of sexual } \\
\text { intercourse, } \\
\text { abstinence, number } \\
\text { of sexual partners and } \\
\text { condom use. }\end{array}$ & $\begin{array}{l}\text { Participants in the intervention } \\
\text { group showed increased } \\
\text { communication about sexual } \\
\text { issues with parents and others, } \\
\text { delayed initiation of sexual } \\
\text { intercourse, increased } \\
\text { abstinence, reduced number of } \\
\text { sexual partners and increased } \\
\text { condom use than those in the } \\
\text { control group. }(\mathrm{p}<0.001)\end{array}$ \\
\hline
\end{tabular}

toward sexual and reproductive health issues in adolescents in sub-Saharan Africa. We advocate for a comprehensive approach to ASRHE programs that involve adolescents, families, schools, community agencies, religious institutions, media, health care providers and government at all levels in order to ensure the provision of quality and sustainable ASRHE programs.

\section{Implications for the Future Research, Practice and Policy.}

The studies included in the review assessed short term impact of ASRHE programs. There is a need for more studies to assess the long term impact of these ASRHE programs in subSaharan Africa. Peer and mass media produced minimal effect on ASRH outcomes. There is a need for more research to identify factors that derail the effectiveness of these programs in the sub-Saharan Africa. It is also recommended that all sub-Saharan countries should introduce ASRH services in workplaces so that adolescents in these places are not left out. Adolescents should also be involved in all ASRHE programs from planning, implementation, and evaluation, in order to instill a spirit of ownership which could eventually ensure sustainability of ASRHE programs. Appreciation of the variability of adolescent development by sex, culture and community is very important. A study conducted in the USA indicated that sexual expression in adolescence and the accompanying sexual behaviors which impact on sexual health have are linked to physical (pubertal), cognitive and psychosocial development (Monasterio, Hwang, \& Shafer, 2007). More research is needed to come up with new interventions or to validate existing, age-specific, peer and culturallysensitive sexual health interventions in subSaharan Africa.

Governments have preexisting structure, authority and resources to maintain a program (Tyndale \& Penwell, 2010). It is therefore important for governments in the sub-Saharan region to make and promote policies that do not only identify or allocate financial resources but promote inter-sectoral collaborations, to promote and sustain ASRHE programs. Stakeholders from all sectors of society need to be identified 
and incorporated in the effort to develop a locally accepted ASRHE program. Communities and parents need to be involved in program development and planning at the onset of ASRHE programs. Without community and parental leadership and active involvement,
ASRHE programs are rarely sustainable.

Acknowledgements

We are grateful to Kate Devis and Precious Madula for editing the manuscript.

\section{References}

Agha, S. (2002). A quasi-experimental study to assess the impact of four adolescent sexual health interventions in Sub-Saharan Africa. International Family Planning Perspectives, 28, 67-70 \& 113-118.

Agha, S., \& Van Rossem, R. (2004). Impact of a school-based peer sexual health intervention on normative beliefs, risk perceptions, and sexual behavior of Zambian adolescents. Journal of Adolescent Health, 34, 441-452.

Akers, A.Y., Youmans, S., Lloyd, S.W., Smith, D.M., Banks, B., Blumenthal, C., ... Adimora, A.A. (2010). Views of young, rural African Americans of the role of community social institutions in HIV prevention. Journal of Health Care for the Poor and Underserved, 21(2 Suppl), 1-12.

Akpabio, I., Asuzu, M., \& Boluwani, R. (2009). Effects of school health nursing education interventions on HIV/AIDS-related attitudes of students in Akwa Ibom State, Nigeria. Journal of Adolescent Health, 44,118-123.

Bernstein, S., \& Hansen, C. (2006). Public choices, private decisions: Sexual and reproductive health and the Millennium Development Goals. New York: United Nations Millennium Project. Available at http://www.unmillenniumproject.org/documents/MP Sexual_Health screen-final.pdf Accessed October 10, 2011.

Boyer, C.B., Sieverding, J., Siller, J., Gallareadc, A., \& Chang, J. (2007).Youth United through health education: Community-level, peer-led outreach to increase awareness and improve noninvasive sexually transmitted infection screening in urban African American youth. Journal of Adolescent Health, 40, 499-505.

Brieger, W., Delano, G., Lane C., Oladepo, O., \& Oyediran, K.A. (2001). West African Youth Initiative: Outcome of reproductive health education program. Journal of Adolescent Health, 29(6) ), 436446.

Cardoza, V.J., Docum, P.I., Fryer S.G., Gold, M.A., \& Butler, J. (2011). Sexual Health Behavior Interventions for U.S. Latino Adolescents: A Systematic review of the literature. Journal of Pediatric and Adolescent Gynecology. doi:10.1016/j.jpag.2011.09.011. Article in Press.

Cupples, J.B., Zukoski, A.P., \& Dierwechter, T. (2010). Reaching young men: Lessons learned in the recruitment, training, and utilization of male peer sexual health educators. Health Promotion Practice, 11(3 Suppl), 19S-25s.

DiClemente, R. J., Wingood, G.M., Harrington, K.F., Lang, D.L., Davies, S.L., Hook, E.W., Robillard A. (2004) Efficacy of an HIV prevention intervention for African American adolescent girls; A randomized controlled trial. Journal of American Medical Association, 292, 171-179.

Erulkar, A, L., Ettyang, C., Onoka, F., Nyagah, A., \& Muyonga A. (2004). Behavioral impacts of a culturally consistent reproductive health program for young Kenyans. International Family Planning Perspectives, 30 (2)58-67.

Esere, M.O. (2008). Effect of sex education program on at-risk sexual behavior of school-going adolescents in Ilorin, Nigeria. African Health Sciences, 8, 120-125.

Fawole, I.O., Asuzu, M.C., Oduntan, S.O., \& Brieger W.R. (1999). A school-based AIDS education program for secondary school students in Nigeria: A review of effectiveness. Health Education Research: Theory \& Practice, 14, 675-683.

Gavin, L.E., Catalano, R.F., \& Markham C. (2010). A Review of positive youth development programs that promote adolescent sexual and reproductive health. Journal of Adolescent Health, 46: S75S91. 
Global Health Council. (2007). Strengthening PEPFAR for women and girls. Policy brief. Washington, DC. Available at: http://www.globalhealth.org/images/pdf/pepfarbrief.pdf. Accessed October 11, 2011.

Jones A.J., Mathews, C. Flisher, J.A. (2011). Can peer education make a difference? Evaluation of a South African adolescent peer education program to promote sexual and reproductive health. AIDS Behavior, 15(8):1605-1611.

Kim, Y.M., Kos, A., Nyakauru, R., Marangwanda, C., \& Chibatamoto, P. (2001) Promoting sexual responsibility among young people in Zimbabwe. International Family Planning Perspectives, 27, 11-19.

Mbizvo, M., Kasule, V., \& Gupta, S. (1997). Effects of a randomized health education intervention on aspects of reproductive health knowledge and reported behavior among Adolescents in Zimbabwe. Journal of Social Science Medicine, 5, 573-577.

Monasterio, E., Hwang, L.Y., \& Shafer M.A. (2007). Adolescent sexual health. Current Problems in Pediatric Adolescent Health Care, 37:302-325.

Muyinda, H., Nakuya, J., Pool, R., \& Whitworth, J. (2003). Harnessing the Senga institution of adolescent sex education for the control of HIV and STDs in rural Uganda. AIDS Care, 15, 159-167.

Okonofua, F.E., Coplan, P., Collins, S., Oransaye, F., Ogunsakin, D., Ogonor J., ... Heggehougen, K. (2003). Impact of an intervention to improve treatment-seeking behavior and prevent sexually transmitted diseases among Nigerian youth. International Journal of Infectious Diseases, 7, 6173.

Pleck, J., Sonenstein, F., \& Leffert, N. (1993). Masculinity ideology: Its impact on adolescent males' heterosexual relationships. Journal of Social Issues, 49, 11-30.

Rani, M., \& Lule, E. (2004). Exploring the socioeconomic dimensions of adolescents reproductive health: A multicounty analysis. International Family Planning Perspectives, 30(3), 110-117.

Roberts, D.F., Foehr, U.G., Rideout, V.J., \& Brodie, M. (1999). Kids and media at the New Millennium: A comprehensive national analysis of children's media use. Menlo Park, CA: Henry J. Kaiser Family Foundation.

Shuey, D.A., Babishangire, B.B., Omiat, S., \& Bagarukayo, H. (1999). Increased sexual abstinence among in-school adolescents as a result of school health education in Soroti District, Uganda. Health Education Research: Theory \& Practice, 14,411-419.

Strasburger, V.C. (2004). Children, adolescents, and the media. Current Problems in Pediatric Adolescent Health Care. 34:54-113.

Sznitman, S., Vanable, P.A., Carey, P., Hennessy, M., Brown, L.K., Valois R.F., Romer, D. (2011). Using culturally sensitive media messages to reduce HIV-associated sexual behavior in high-risk African American adolescents: Results from a randomized trial. Journal of Adolescent Health, 49, 244-251.

Tyandale, M., \& Penwell, J. (2010).Peer-led interventions to reduce HIV risk of youth: A review. Penwell Barnett. Evaluation and Program Planning, 33, 98-112.

UNAIDS. (2008). Report on the Global AIDS Epidemic, New York. Available at http://www.unaids.org/en/dataanalysis/epidemiology/2008reportontheglobalaidsepidemic/. Accessed October 12, 2011.

United Nations. World economic situation and Prospects. (2011), New York. Available at http://www.un.org/en/development/desa/policy/wesp/wesp current/2011wesp.pdf. Accessed October 10, 2011.

UNFPA. (2011). Fact sheet: young people and times of change. Available at http://www.unfpa.org/public/home/factsheets/young people. Accessed October 10, 2011.

UNFPA. (2010). The ICPD AND MDGS: Close linkages. Available at http://www.un.org/esa/population/publications/PopAspectsMDG/14_UNFPA.pdf. Accessed May 29. 2012.

USAID. (2009). Healthy Policy initiative; Facts sheet on youth reproductive health policy: Poverty and youth reproductive health. Available at 
http://www.healthpolicyinitiative.com/Publications/Documents/975_1_Poverty_YRH_FINAL_ac c.pdf . Accessed October 10, 2011.

WHO. (2011). Facts sheet why is giving special attention to adolescents important for achieving Millennium Development Goal 5. Available at http://www.who.int/making pregnancy safer/events/2008/mdg5/adolescent preg.pdf .Accessed October 5, 2011.

Author Information

*Fatch W. Kalembo, MPH

Huazhong University of Science and Technology

Maternal and Child Health Department

Tongji Medical College

Hang Kong Lu

430030 Wuhan China

Email:kalembofatch@yahoo.com

Telephone: +8615271811322

Fax: +862787532754

Maggie Zgambo, B.Sc.N

University of North Carolina Project

Lilongwe, Malawi

Du Yukai, PhD

Huazhong University of Science and Technology

* corresponding author 